\title{
Lifestyle and cancer prevention in female employees at a health institution
}

\author{
Gladys Eugenia Canaval, PhD ${ }^{1}$, María Neila Sánchez, MSc ${ }^{2}$
}

\section{SUMMARY}

Objective: To establish the relationship between lifestyle for prevention of cervix and breast cancer and perceptual cognitive factors from the Pender model in working women.

Materials and methods: Correlation and cross-sectional study with a random sample of 143 working women. The Lifestyle index is the total score of 5 variables: Papanicolau test, breast self-exam, physical activity, body mass index, and cigarette smoking.

Results: The mean age for the sample was $44.4 \pm 6.2$; $87 \%$ of the women had higher education and $85 \%$ were working in health care services. A total of $89 \%$ of the women had unhealthy lifestyles because of the lack of regular physical activity, not having a Papanicolau test according to the norm, not practicing breast self-exams, and having an altered body mass index. There was significant correlation between lifestyle and occupation, and also with self-efficacy perception for breast selfexamination.

Conclusion: The lifestyles for most of the women sampled were unhealthy.

Recommendations: It is recommend the reorientation of health services based on health promotion, which permit planning and executing health care, health education and nursing care programs specifically for working women. It is also recommend conducting culturally sensitive healthcare campaigns in addition to setting up flexible attention schedules for women.

Keywords: Lifestyle; Healthcare promotion; Prevention; Cancer; Working women; Healthcare institution; Nursing care.

Colomb Med. 2011; 42: 177-83

Estilo de vida y la prevención de cáncer en mujeres trabajadoras en una institución de salud

\section{RESUMEN}

Objetivo: Establecer en mujeres trabajadoras la relación entre el estilo de vida para la prevención del cáncer de cérvix y de mama con factores cognitivos perceptuales del modelo de Pender.

Material y métodos: Estudio correlacional de corte transversal. La muestra estuvo conformada por 143 mujeres trabajadoras captadas de manera aleatoria. El índice estilo de vida se calificó de acuerdo con el total obtenido de la suma de cinco variables: la citología cervicouterina, el autoexamen de mama, el ejercicio, el índice de masa corporal y el hábito de fumar.

Resultados: El promedio de edad para la muestra fue $44.4 \pm 6.2$; un alto porcentaje (87\%) con educación superior; $85 \%$ laboraban en área asistencial en salud. Para 89\% de las mujeres trabajadoras el estilo de vida fue no saludable, a expensas de no hacer ejercicio regularmente, no realizarse la citología cervicouterina, no realizar el autoexamen de mama con la autoeficacia ni con la frecuencia y en el tiempo adecuado y tener el índice de masa corporal aumentado para un alto porcentaje de ellas. Se observó relación significativa del estilo de vida sólo con las variables ubicación laboral y percepción de autoeficacia para realizar el autoexamen de mama.

Conclusiones: El estilo de vida para la mayoría de las mujeres de la muestra no es saludable. Se recomienda la reorientación de los servicios de salud con base en la promoción de la salud, lo cual permitirá planear y ejecutar programas de atención y educación para la salud y de cuidado de enfermería específicos para la mujer trabajadora, campañas educativas y culturalmente sensibles, horarios flexibles o cómodos para las mujeres.

1. Professor, Nursing School, Health Division, Universidad del Valle, Cali, Colombia. e-mail: gladys.canaval@correounivalle.edu.co

2. Professor, Nursing School, Health Division, Universidad Santiago de Cali, Cali, Colombia. e-mail:marianeila27@yahoo.es

Received for publication July 13, 2009 Accepted for publication April 13, 2010 
Palabras clave: Estilo de vida; Promoción de la salud; Prevención; Cáncer; Mujeres trabajadoras; Institución de salud; Cuidado de enfermería.

Colomb Med. 2011; 42: 177-83

Healthcare promotion deals fundamentally with the action destined to addressing the set of potentially modifiable health determinants, not only those related to actions of individuals, like behaviors and healthy lifestyles, but also to determinants like income and social status, education, work and work conditions, access to adequate healthcare services, and a healthy physical environment.

Women's health is related to healthcare promotion and specific protection, early diagnosis, opportune treatment, disability management, all frameworked within the family, social, labor, economic, cultural, and educational contexts in which they live and not only to their reproductive health ${ }^{1}$.

Regarding breast and cervix cancer, in spite of accomplishments reached in prevention, early diagnosis, and treatment, they are among the leading causes of death worldwide ${ }^{2,3}$; they are considered a public health problem around the world ${ }^{4-6}$. Cancer is a multi-causal, chronic, silent disease, which in many instances may be prevented under certain living conditions and may be cured when the diagnosis is performed during the early stages of the disease. Particularly, breast and cervix cancer endanger the lives of women in many parts of the world and in Colombia these pathologies are among the leading causes of mortality in women over 40 years of age $^{7-9}$. This underscores the importance of lifestyle and self-care, which involve aspects related to balanced nutrition, periodic physical activity, weight control, breast self-examinations with self-efficacy, routine medical exams, Papanicolau exams, awareness of the dangers derived from consuming alcoholic beverages, and cigarette smoking.

In addition to environmental influences, women's health is also determined by the care they practice according to their knowledge, beliefs, and abilities. Healthcare of self-care is not only applicable for health promotion and preservation, but also for the prevention of disease and recovery when health has been altered by any cause; making it necessary for each individual to identify those risk factors that can worsen health conditions and impede opportune and satisfactory recovery processes.

The conceptual framework guiding this study is Pender's Healthcare Promotion Model, which emerged during the 1980s. Based on the results of its application to research, it has evolved into the revised healthcare promotion model ${ }^{10}$. The model shows the multidimensional nature of the interactions individuals have when carrying out actions to promote and maintain their health; the components of the model are the individual characteristics, specific behaviors, cognitive factors and affection, which determine behavioral results. Some model and lifestyle variables used were understood as a set of actions performed by individuals in their daily lives. People can contribute importantly to their own health by adopting conducts related to health and avoiding others; these are the behaviors that highlight the lifestyle ${ }^{11,12}$.

The purpose of this study was to contribute to the field of knowledge on lifestyles of women working in the healthcare sector, with respect to preventive care of breast and cervix cancer based on components from Pender's Healthcare Promotion Model. The following research question was made: What is the relationship among some perceptual-cognitive factors and personal modifiers and the lifestyles adopted by women working in a healthcare institution in Cali to prevent breast and cervix cancer?

\section{MATERIALS AND METHODS}

This was a correlation, cross-sectional study, the population was made up of 512 adult working women from a healthcare institution offering third-level healthcare services in the city of Cali, in Colombia's southwest.

Inclusion criteria included adult women, working and employed in a healthcare institution. We excluded women with uterine cervix or breast pathology at the moment of the study. The sample was calculated by following the guidelines given by experts in this field ${ }^{13}$ based on power analysis, with two-tailed tests, a 95\% power, $5 \%$ for the level of significance and a 0.30 effect of critical size, yielding as a result in the Master Table 124 individuals. The sample was adjusted to 137 and it was taken slightly larger to replace losses; the final N was 143 women distributed in the healthcare and 
Table 1

Independent variables

Perceptual cognitive factors

Importance of health

Perception of health status

Importance of Breast self-exam - BSE

Importance of uterine cervical cytology - UCC

Perceived barriers - BSE and UCC

Self-efficacy for BSE

\section{Modifying, personal factors}

administrative areas. A random sampling was performed based on the list of adult individuals of female sex who worked in the institution; the data were gathered during the period from August 2004 to May 2005.

For this study, the dependent variable was «Lifestyle (LS)» for the prevention of breast and cervix cancer; LS was operationally defined as the index made up by the variables: breast self-exam (BSE), uterine cervical cytology (UCC), cigarette smoking, physical exercise, and Body Mass Index (BMI), this last variable reflects the weight of the women. Each of these variables, except for cigarette smoking, was measured with scores from 0 (not performed), 1 (performed without criteria qualifying it as an adequate practice), and 2 (performed adequately); cigarette smoking was scored, 0 (Yes) and 2 (No). The total LS score was obtained by adding the five variables, the score ranged between 0 and 10 ; scores between 8 and 10 indicated a healthy lifestyle.

The independent variables were the modifying and perceptual-cognitive factors according to Pender's Healthcare Promotion Model, adapted for this study (Table 1).

Information was collected through a 27 -item questionnaire designed for this study. The statements were taken from the literature review on healthy lifestyles ${ }^{14}$.

The questionnaire was applied via a survey technique, through a personal interview. To validate the contents of the instrument, it was reviewed by three research experts on the topic and a pilot test was conducted to make adjustments to it. Reliability was measured via Cronbach's Alpha coefficient whose result was of 0.53 .
The study was approved by the Institutional Ethics Committee and authorized by the directors of the healthcare institution where the sample was collected. The women signed an informed consent and confidentiality and anonymity was guaranteed.

\section{RESULTS}

Characteristics of the sample. The women ranged from 26 to 58 years of age (mean of $44.4 \pm 6.2$ ); of these, $59 \%$ were married or in common-law marriage. Regarding schooling, $87 \%$ of them had university or technical studies; occupation revealed that $85 \%$ worked in the healthcare area (Table 2).

Personal, modifying, and perceptual-cognitive factors. Table 3 presents the results of percentage distribution according to modifying factors and personal factors. The Perceptual-Cognitive factors are shown in Table 2. Some $97.2 \%$ of the women considered it very important to perform the breast self-exam, but only $34.3 \%$ performs it every month, $72.9 \%$ stated being able to perform it although in the question about barriers to perform the BSE, 54\% expressed having difficulties when performing it. Regarding the uterine cervix cytology, all the women in the study considered it of utmost importance, but $51 \%$ did not have it done periodically, they have it done at intervals of up to five years; only $21 \%$ of them have it done yearly.

Barriers perceived. The barriers keeping women from having uterine cervix cytology are: fear of pain, fear of the procedure, they forget, and a sense of shame. The barriers keeping women from performing breast 
Table 2

Percentage distribution of women according to modifying and personal factors

\begin{tabular}{llc}
\hline & & \% of women \\
\hline \multirow{3}{*}{ Marital status } & Stable union & 59 \\
& Single and separated & 36 \\
& Without data & 5 \\
& Total & 100 \\
\cline { 3 - 3 } Occupational area & Employed in the healthcare area & 85 \\
& Employed in the administrative area & 14 \\
& Without data & 1 \\
& Total & 100 \\
& Primary school & 1 \\
& Secondary school & 11 \\
& Postsecondary & 87 \\
& Professionals & 22 \\
& Healthcare field & 19 \\
& Administration field & 3 \\
& Technicians and technologists & 61 \\
& Studied but no title held & 4 \\
& Without data & 87 \\
& Total & 1 \\
\hline
\end{tabular}

Table 3

Percentage distribution of women's responses according to modifying, personal, and perceptual cognitive factors

\begin{tabular}{lc}
\hline & $\%$ \\
\hline Modifying, personal factors & \\
Personal antecedents of cervix cancer & 20 \\
Personal antecedents of breast pathology & 18 \\
Family antecedents of breast cancer & 22 \\
Perceptual cognitive factors & 100 \\
Importance of health & 93 \\
Perception of a good state of health & 97 \\
Importance of breast self-exam - BSE & 99 \\
Importance of the uterine cervical cytology (UCC) &
\end{tabular}

self-exam are: difficulty with the technique to perform the exam and lack of interest.

Lifestyle. The index measuring lifestyles of the women sampled was within values qualifying it as healthy merely for $11 \%$ of the cases. Among the women with a total LS score below 8, i.e., with an unhealthy lifestyle, some did not adequately perform the BSE (49\%), because of poor skills or inadequate periodicity, 
or because they never practiced it (17\%); the Body Mass Index (BMI) contributed to this unhealthy lifestyle, whose result revealed data beyond the normal limits for $49 \%$ of the women sampled (Tabla 4); another aspect contributing to unhealthy LS was the lack of periodic exercise for $79 \%$ of the women and not having a uterine cervical cytology done according to the periodicity established in national guidelines for $74 \%$ of them; $13 \%$ of the women responded positive for the «cigarette smoking» variable.

The correlation of LS with the determinant variables resulted significant for the «place of work» variable (administrative area or healthcare area) with healthier LS for women working in the administrative area $\left(\mathrm{Chi}^{2}\right.$ 9.3, $\mathrm{p}<0.5)$. Likewise, LS was significantly correlated with the perception of self-efficacy for BSE, (Pearson correlation, $r=0.87 \mathrm{p}<0.5$ ); a positive correlation was also obtained between self-efficacy for BSE and the level of schooling (Pearson correlation, $r=0.35, \mathrm{p}<0.5$ ).

\section{DISCUSSION}

The lifestyle for most of the working women sampled is an unhealthy lifestyle, this result is cause for concern for women and the healthcare sector, as well as for society in general, more so if more than $85 \%$ of these women work in the healthcare area and a high percentage of them had higher levels of schooling. It is expected that women with higher education, with social security, and very close to healthcare services exhibit conducts or actions in search of promoting health and easily accede to healthcare programs. It is fitting to inquire: what are the healthcare promotion actions they carry out? What individual aspects and which ones from the external environment become obstacles? What factors keep working women from going to screening tests and early diagnosis tests? It is well-known that the use of healthcare services depends on individual aspects and on aspects from the external environment ${ }^{15}$; education, for example, is related to adequate health results ${ }^{16}$.

Another variable, which was part of the lifestyle, with a low score was physical exercise; only $21 \%$ of the women practiced it with a recommended duration and frequency. Questions arise; what are the barriers, limitations, and difficulties women have to engage in exercise or physical activity? What are the facilitating factors for women who adequately perform physical
Table 4

\section{Percentage distribution of women according to Body Mass Index}

\begin{tabular}{lc}
\hline Value of Body Mass Index & $\%$ \\
\hline Under 18 & 2 \\
$18-24.9$ & 51 \\
$25-29.9$ & 38 \\
Equal to or greater than 30 & 9 \\
\hline
\end{tabular}

exercise? These questions need to be further studied in future research with a quantitative and qualitative approach to better understand these aspects and, thus, contribute to the implementation of measures that help women to improve their lifestyles not merely from the personal sense but from community and collective aspects. For example, women could have difficulties with exercise out in the open in unsafe communities, for fear of urban violence. The efficacy of physical activity as a health benefit is without discussion; the lack of exercise could also be due to lack of time or to working double or triple work shifts.

Another element to consider are the barriers to practicing the BSE; they perceived themselves as selfefficient but at the same time reported having no clarity with respect to the technique of the self exam, this was their main obstacle. The results indicate the need for health education on issues like the technique to practice the BSE and the use of strategies that permit them to remember the periodicity of the exam. The usefulness of educational programs has been shown in increased awareness of cancer and increased practices like the $\mathrm{BSE}^{17}$.

Regarding uterine cervical cytology (UCC), few women have the UCC done on a yearly basis (26\%). If we compare these results to those by Díaz and Frutos ${ }^{18}$ who showed that $52 \%$ of the adult women surveyed in Cali's Commune 11 (mid and low socioeconomic level, with a high percentage of women registered to the subsidized healthcare security regime) had had a uterine cervical cytology within the last year and with the $50.4 \%$ reported for Cali by the National Survey on Demography and Health (ENDS) $2005^{19}$, the results of the current study are very low.

This leads us to think that the campaigns on UCC are insufficient; thus, participatory work is recommended 
with women from early ages, emphasizing on stimuli to have this test done and using positive messages; using negative messages leads to fear, in effect, this was one of the barriers mentioned by the women in this study. Shame was another barrier keeping women from having the exam done; women need to be supported to diminish the shame, this finding is similar to reported by Lagoueyte $^{20}$.

The other unfavorable component for lifestyle in this study was body weight; according to the BMI results, only half the women presented normal values. A high proportion is overweight and another lower percentage is decidedly obese, indicating that intervention programs are required for women emphasizing on nutrition and healthy diet in addition to engaging in physical activity, as previously mentioned.

Regarding cigarette smoking, the proportion of women responding positively is lower than the values reported in adolescent women in the nation; it is similar to cigarette smoking in adults and high if compared to data from pregnant women who smoke Cali and in Valle del Cauca ${ }^{19,21,22}$. These results urge the continuation of anti-tobacco policies given that cigarette smoking is a cause of premature morbidity and mortality in the world ${ }^{23}$.

Implications and recommendations. These results bear implications in planning actions from services to increase the induced demand and health education. Interventions are recommended guided by Pender's Healthcare Promotion mode ${ }^{10}$, which contemplates strategies for high-intensity action to contribute to motivating having UCCs done, to diminish the barriers, and in general to go to other screening tests.

Associating LS to variables stated according to the Healthcare promotion model adopted for this study did not reveal significance except for the variable of selfefficacy for the BSE, which could indicate that it is fitting to include other variables and adjust the conceptual framework that guided the research and the applied questionnaire, according to the current revised Healthcare promotion model.

Self-efficacy influences the perceived action barriers, the greater efficacy leads to the perception of fewer barriers to perform this conduct; this study found that self-efficacy for the breast self-exam is significantly and negatively related to the difficulties or barriers for the BSE, i.e., greater self-efficacymeans lower difficulty to perform the BSE. This variable, self-efficacy, was also significantly and positively related to schooling, indicating that as level of schooling increased so did the ability for the self-exam.

We recommend studying other specific determinants that lead to a healthy lifestyle; according to Pender et al. ${ }^{10}$, these could be perceived benefits, personal and situational influences, and skills demands.

Planning and execution of permanent healthcare programs are recommended for working women including nursing care for health promotion.

Reorientation of services is recommended with emphasis on healthcare promotion, this objective has been suggested in International Healthcare Promotion conferences. It is important to make sure that healthcare services are women friendly, with lower costs and nonconventional schedules. It would also be of great help to integrate cancer prevention services with other healthcare services frequented by women. Additionally, it is advisable to promote health in the workplace, along with welfare plans at work with incentives like physical conditioning facilities, flexible schedules for the physical activity and relaxation, etc.

\section{CONCLUSIONS}

The lifestyles of women were healthy only for a very small number of the women participating in the study. A high percentage of them did not regularly engage in physical exercise, did not seek services to have the uterine cervix cytology, did not opportunely perform the breast self-exam, and were overweight or obese. The women have barriers for having a vaginal cytology and to perform the breast self-exam.

Final considerations. Cancer, with the stigma it still has as a degenerative disease with pain, suffering, and of a death sentence if it is not detected early, becomes a taboo for the population in general; carrying out healthy actions to prevent breast cancer tends to be ignored by women. Insisting on nursing care, on prevention and on health promotion based on collective and individual actions, on education for health, and on programs founded on healthy public policies that guide the strategies for early detection and the accomplishment of healthy lifestyles must be constant. In general, this study shows that most women do not develop prevention habits regarding cervix and breast cancer. Poor skills 
for the BSE, shame, and lack of interest are barriers that must be addressed with the women themselves; thereby, we must insist on healthcare promotion and on the development of skills to accomplish such.

\section{RECOMMENDATIONS}

It is highly recommended to include women in the design, practice, and assessment of healthcare promotion and cancer prevention programs. Education in Health must be understood as a long-term task, with all women and healthcare agents to contribute to creating healthy habits. This education demands time and patience and requires everybody's commitment. Cancer prevention programs must address the issue of cultural, emotional, and practical barriers influencing on how women use screening services. Participation of women in designing the programs contributes to ensuring that members from the target population receive convincing information from preferred sources and to developing messages that reach women, messages adapted to the cultural characteristics of the target population.

Limitations of the study. This is a transversal study that permits describing and finding associations, but does not study causality, although the sample was randomly selected. Given the reliability of Cronbach's Alpha instrument at 0.53 , it is necessary to revise such and exclude irrelevant statements or questions like the measurement of the importance of health for women and the importance of UCC and BSE; almost all the women answered affirmatively to these questions. The results are applicable to working women in third level of attention healthcare institutions.

Conflict of interest. None of the authors has conflicts of interest related to this study.

\section{REFERENCES}

1. World Health Organization (WHO). Women's health 2009. [Access May 2009]. Available in: G: $\backslash A S \backslash B I B$ AS Memory minilwomen health $\backslash$ OMS Women Health $\backslash$ WHO Women's health.mht

2. Litaker D, Tomolo A. Association of contextual factors and breast cancer screening: Finding new targets to promote early detection. J Women Health. 2007; 16: 36-47.

3. OPS. Género, salud y desarrollo en las Américas, 2003. [Access July 30, 2008]. Available in: http://www.isis.cl/temas/salud/dicenque.htm\#col
4. Mejía A, Salas W. Costo-efectividad de la detección del virus del papiloma humano en los programas de tamización de cáncer de cuello uterino. Biomedica. 2008; 28: 160-72.

5. Porter P. Global trends in breast cancer incidence and mortality. Rev Salud Publica Mex. 2009; 51 (Supl 2): S141-6

6. Instituto Nacional de Cancerología (INC). Anuario estadistico. Volumen 4. Bogotá: INC; 2006.

7. Hernández G, Herrán S, Cantor LF. Análisis de las tendencias de mortalidad por cáncer de mama en Colombia y Bogotá, 1981-2000. Rev Colomb Cancerol. 2007; 11: 32-9.

8. American Cancer Society. Global cancer statistics, 2002. Cancer J Clin. 2005; 55: 74-108.

9. Wiesner C. Determinantes psicológicos, clínicos y sociales del diagnóstico temprano del cáncer de mama en Bogotá, Colombia. Rev Colomb Cancerol. 2007; 11: 13-22.

10. Pender N, Murdaugh CL, Parsons MA. Health promotion in nursing practice. $5^{\text {a }}$ ed. New Jersey: Pearson/Prentice Hall; 2006. p. 47.

11. WHO. The World Health Report 2002. Reducing risks, promoting healthy life. Geneva: WHO [Acceso Dic 2002]. Available in: http://www.who.int

12. Brønnum-Hansen H, Juel K, Davidsen M, Sørensen J. Impact of selected risk factors on expected lifetime without longstanding, limiting illness in Denmark. Prev Med. 2007; 45: 49-53.

13. Kraemer HC, Thiemann S. How many subjects? Statistical power analysis in research. Thousand Oaks: Sage; 1987. p. 120.

14. Goldbaum M. Estilos de vida y modernidad. Centro Internacional de Investigaciones para el Desarrollo (IDRC). [Access 12 June 2006]. Available in http://www.idrc.ca/lacro/ev23071-201-1-DO_TOPIC.html

15. Andersen RM, Yu H, Wyn R, Davidson PL, Brown ER, Teleki S. Access to medical care for low-income persons: How do communities make a difference? Med Care Res Rev. 2002; 59: 384.

16. Veugelers PJ, Yip AM, Kephart G. Proximate and contextual socioeconomic determinants of mortality: Multilevel approaches in a setting with universal health coverage. Am J Epidemiol. 2001; 154: 725.

17. Soyer MT, Ciceklioglu M, Ceber E. Breast cancer awareness and practice of breast self examination among primary health care nurses: influencing factors and effects of an in-service education. J Clin Nurs. 2007; 16: 707-15.

18. Díaz MT, Frutos M. Aumento de la citología cérvico-uterina en mujeres de la Comuna 11 de Cali. Trabajo de investigación, Especialización en Promoción de la Salud. Convenio Universidad de Caldas y Universidad del Valle, Cali; 2003.

19. Profamilia. Resultados Encuesta Nacional de Demografia y Salud (ENDS). Bogotá: Profamilia; 2005. p. 208, 384.

20. Lagoueyte MI. La citología vaginal mirada desde las mujeres. Inv Ed Enf. 2002; 20: 58-69.

21. Wiesner C, Peñaranda D. Encuesta mundial de tabaquismo en jóvenes reporte de Bogotá, Colombia. Rev Colomb Cancerol. 2002; 6: 5-14.

22. Condiciones de salud en Cali. Memorias Foro Municipal por la Salud de Cali, julio 10 de 2007. Cali: CEDETES, Universidad del Valle.

23. Samet J. Los riesgos del tabaquismo activo y pasivo. Salud Publica Mex. 2002; 44 (Supl): 144-59. 